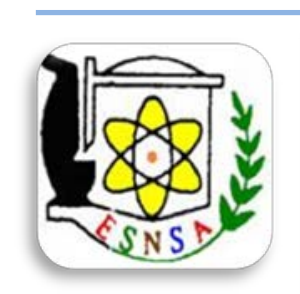

ISSN 1110-0451

\section{Arab Journal of Nuclear Sciences and Applications}

Web site: ajnsa.journals.ekb.eq

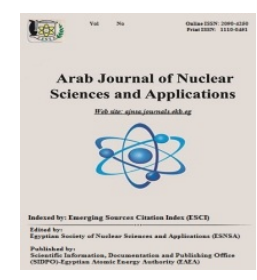

(ESNSA)

\title{
Surface-Groundwater Interaction in the Area between El-Timsah Lake and Ismailia Canal Using Hydrochemical and Isotopic Techniques
}

\author{
H.B. Hassan, R.A. Rayan and R.A. Hussien \\ Egyptian Nuclear and Radiological Regulatory Authority
}

Received $1^{\text {st }}$ Jan 2020 Accepted $13^{\text {rd }}$ Feb 2020

\begin{abstract}
An attempt was made to understand how surface-groundwater interaction and impact both water quality and quantity in the area between El-Timsah Lake and Ismailia Canal, Egypt. Twenty one surface and groundwater samples were collected from the study area. Hydrochemical data revealed that total dissolved solid (TDS) of Ismailia Canal and groundwater samples ranged from 328 to 613 and 345.7$1099 \mathrm{mg} / \mathrm{l}$ respectively. Salinity of El-Timsah Lake samples ranged from 16730 to $34560 \mathrm{mg} / \mathrm{l}$. The lowest salinity was existed in the middle and western edge of the lake which indicates the discharge of Ismailia Canal and drainage water into the lake. According to drinking water quality index (DWQI), most of groundwater is suitable for drinking purposes, but some wells in the study area were threatened due to increasing salinity. Highest values of nitrate and phosphate concentration in groundwater reached 53.4 and $1.8 \mathrm{mg} / \mathrm{l}$ respectively which are slightly above permissible limits. Also, the concentrations of trace elements ( $\mathrm{Al}, \mathrm{B}, \mathrm{Fe}, \mathrm{Mn}, \mathrm{pb}, \mathrm{Mo}, \mathrm{Si}$ and $\mathrm{Sr}$ ) in some surface and groundwater samples exceeded the international standard limits. The increase of nitrate, phosphate and some trace elements concentration may be fed rapid pollution path to the underlying, shallow aquifers which may have impact on groundwater quality. Stable isotopes $\left(\delta^{18} \mathrm{O}\right.$ and $\left.\delta^{2} \mathrm{H}\right)$ of groundwater samples ranged from 2.54 to $3.39 \%$ and 22.95 to $27.79 \%$ respectively. The isotopic content $\left(\delta^{18} \mathrm{O}\right.$ and $\left.\delta \mathrm{D}\right)$ of groundwater is similar to the isotopic content value of the recent Nile water and Ismailia Canal. This confirms that Ismailia Canal and drainage water are considered a recharge source for the unconfined aquifer.
\end{abstract}

Keywords: Hydrochemical evolution, water quality index, water interactions, Environmental isotopes, Ismailia Canal, Egypt

\section{Introduction}

Ismailia City is located on El- Timsah Lake and includes many activities as navigation, intensified industrial and agricultural activities. It suffers from high rates of population growth. Ismailia Canal is the main canal in the Ismailia city and fed by water from the Nile. Wadi El- Tumilat running E-W from the present Nile Delta was most probably the course that delivered the Nile water to Suez Canal area. [1] Quaternary Aquifer of Wadi El Tumilat (QAWT) represents the main aquifer in the study area.

There are a number of surface water bodies in the study area; such bodies include Irrigation canals of fresh Nile water (e.g Ismailia Canal). El Mahsama drain is the main drainage in the study area. Most of the houses in Ismailia City are connected to the municipal sewerage system. The partially treated wastewater discharges into El- Mahsama agricultural drainage, which discharges its load into the western lagoon from which water passes into the El -Timsah Lake. El- Timsah Lake receives different water types including both freshwater from the outlet of Ismailia Canal and waste water discharging into the western side of the lake which represents most of the pollution load into lake [2]. 
Measurement of the environmental isotopes in surface and groundwater in the study area were conducted to explore surface interactions between Ismailia Canal, El-Timsah Lake and groundwater aquifer. Groundwater is used for domestic, agricultural and livestock activities in Ismailia city. Therefore, a hydrogeochemical investigation was carried out to identify hydrochemical parameters variation and distribution, water types, hydrochemical facies, stage of salinization and water quality.

\section{Site description}

The study area lies between $30^{\circ} 32^{\prime} 25^{\prime \prime}$ to $30^{\circ} 35^{\prime}$ $18^{\prime \prime} \mathrm{N}$ and $32^{\circ} 13^{\prime} 17^{\prime \prime}$ to $32^{\circ} 18^{\prime} 35^{\prime \prime} \mathrm{E}$ at the central province of Suez Canal area. It includes Wadi El Tumilat, Ismailia Canal and El-Timsah Lake along the coast of the Suez Canal. Wadi El Tu milat dissected Ismailia city and attached El- Timsah Lake. El-Timsah Lake is considered the biggest water body at Ismailia City with a surface area of $14 \mathrm{~km}^{2}$. It is a saline shallow water basin as shown in Fig. (1).

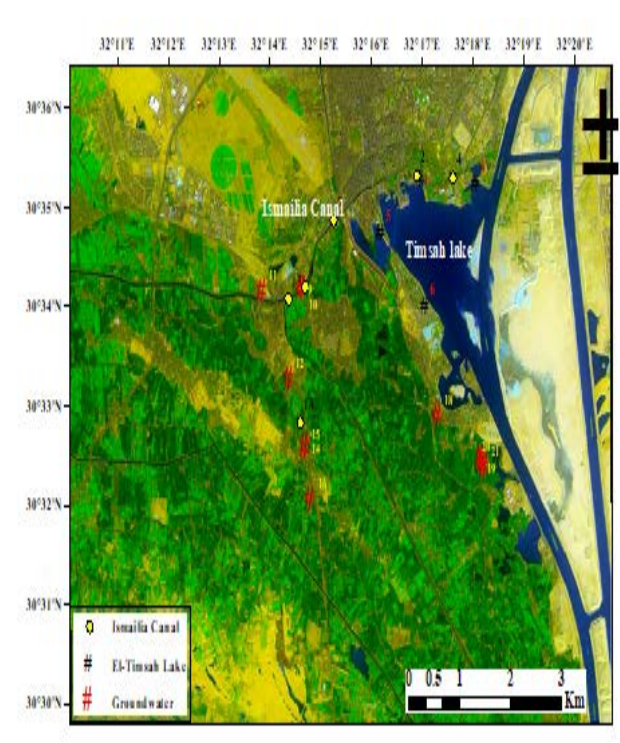

Fig. (1): Location samples in the study area

The study area is characterized by desert climate, with arid, hot and rainless summer and mild winter with low precipitation and high rate evaporation [3].

\section{Geomorphological setting}

Geomorphologically, the study area is delineated by Wadi El-Tumilat which represents a part of the eastern gravelly slopes fringing the Nile Delta and acting as water discharging basin. Wadi El-
Tumult running E-W from the present Nile Delta along stable, low-elevation ground the top surface elevation slopes in the study area began from $29 \mathrm{~m}$ at the northwestern part to $-1 \mathrm{~m}$ to Timsah Lake. Wadi El- Tumult was most probably the course that delivered the Nile water to Suez Canal area [1] and it is occupied by Ismailia fresh-water canal. Also, El-Timsah Lake acts as natural branch discharging areas.

Quaternary Aquifer of Wadi El Tumilat (QAWT) in the study area represents the main aquifer in the region and composed of fluviatile and fluviomarine graded sand and gravel with clay intercalations of limited extension. The surface area surrounding Suez Canal is occupied by sedimentary rocks belonging to the late Tertiary (Miocene and Pliocene) and to the Quaternary [4] as shown in Fig. (2)

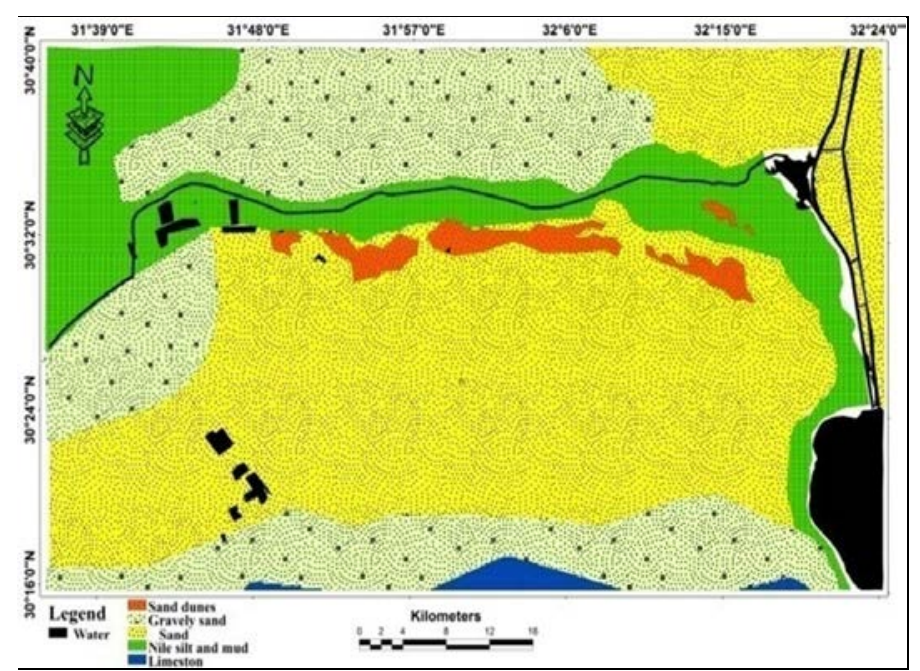

Fig. (2): Geologic map of study area (after Geriesh1994).

Several studies have been conducted on the study area for evaluating the surface and groundwater resources. Among the most important of these studies are those by Geriesh, and El Shamy [5, 6]. They used the classical hydrological tools for investigating the flow and recharge conditions of the surface and groundwater resources in the study area. The present study investigates the update tools of environmental isotopes with water quality index for more insight on the interaction between surface and groundwater in this important area.

\section{Material and Methods}

Sampling and Analytical procedures

Twenty one water samples (10 surface and 11groundwater samples) were collected during the sampling campaign in 2019 and the location of the 
sampling sites were recorded using a Global Positioning System model GARMIN as shown in Fig. (1). Temperature, Oxidation-Reduction Potential (ORP), Dissolved Oxygen (DO), pH, Electrical Conductivity (EC), and Total Dissolved Solids (TDS) were measured in situ utilizing portable meters the portable Manta 2, WaterQuality Multi probe device, Model Sub 3, USA. Chemical and stable isotope analysis of the water samples collected from the study area were carried out in the Central Laboratory of Stable Isotope Hydrology at the Nuclear and Radiological Regulatory Authority. APHA (1995), titrimetric methods were used to determine $\mathrm{Mg}^{2+}, \mathrm{Ca}^{2+}$, $\mathrm{HCO}_{3}{ }^{-}$, and $\mathrm{Cl}^{-}$. Sodium $\left(\mathrm{Na}^{+}\right)$and potassium $\left(\mathrm{K}^{+}\right)$ which were measured using a flame photometer (Jenway). Sulphate $\mathrm{SO}_{4}{ }^{2-}$ Nitrate $\mathrm{NO}_{3}{ }^{-}$and $\mathrm{PO}_{4}{ }^{3-}$ concentrations were analyzed using UVSpectrophotometer (UV- 1600 Shimadzu). Water quality parameters are expressed in $\mathrm{mg} / \mathrm{l}$ and meq/l. Trace elements (Al, B, Ba, Bi, Cd, Co, Cr, $\mathrm{Cu}, \mathrm{Fe}, \mathrm{Mn}, \mathrm{Mo}, \mathrm{Ni}, \mathrm{Pb}, \mathrm{Si}, \mathrm{Sr}, \mathrm{V}$, and $\mathrm{Zn}$ ) were measured using ICP Mass Inductively Coupled Plasma in Desert Research Centre (DRC). Stable isotopes $(\delta \mathrm{O}-18$ and $\delta \mathrm{D})$ in water samples were measured using Picarro Laser Spectroscopy.

\section{Drinking Water Quality Index (DWQI)}

The Water Quality Index (WQI) was used to evaluate the collected water samples and its suitability for drinking purposes. [7] This index is based on a combination of three factors, scope F1, frequency F2, and amplitude F3. Nineteen hydrochemical parameters have been selected as variables from the data set of the chemical analyses of the groundwater samples collected from the study area. These have been compared with the corresponding objectives values in the [8] Egyptian High Committee of Water Guidelines for Drinking Water Purposes. After the variables and the objectives have been defined, each of the three factors (F1, F2, and F3) that make up the Canadian Council of Ministers of the Environment (CCME WQI) Water Quality index is calculated according to the method adopted by Canadian Environmental Quality Guidelines (2001). The definition of the different parameters used in the calculation of the index and the equations used are described as follows:

$\underline{F 1}$ (Scope) represents the percentage of variables that do not meet their objectives at least once during the time period under consideration "failed variables", relative to the total number of variables measured:

\section{$F 1=$ (Number of Failed Variables/Total Number of Variables) X 100}

F2 (Frequency) represents the percentage of individual tests that do not meet objectives ("failed tests"):

\section{$F 2=($ Number of Failed Variables/Total Number of Variables) X 100}

F3 (Amplitude) represents the amount by which failed test values do not meet their objectives. F3 is calculated in three steps. The number of times by which an individual concentration is greater than (or less than, when the objective is a minimum) the objective is termed an "excursion" and is expressed as follows, when the test value must not exceed the objective:

\section{excrusion $_{i}=\left\{\left({\text { Failed Test } \text { Value }_{\mathrm{i}} / \text { Objective }}\right.\right.$ j)\}-1}

The collective amount by which individual tests are out of compliance is calculated by summing the excursions of individual tests from their objectives and dividing by the total number of tests (both those meeting objectives and those not meeting objectives). This variable, referred to as the normalized sum of excursions or nse, is calculated as:

$$
\text { nse }=\sum_{i=1}^{n} \text { excrusion }_{i} / \text { no of Tests }
$$

i) F3 is then calculated by an asymptotic function that scales the normalized sum of the excursions from objectives (nse) to yield a range between 0 and 100 .

\section{$F 3=\{$ nse $/(0.01 n s e+0.01)\}$}

Once the F1, F2 and F3 factors have been determined, the overall water quality index CCMEWQI can be calculated by summing the three factors as if they were vectors according to the following equation:

CCMEWQI $=100-\left\{\sqrt{ }\left(F_{1}{ }^{2}+F_{2}{ }^{2}+F_{3}{ }^{2}\right)\right\} / 1.732$ 
The overall value of the index helps to classify the water samples into different categories according to drinking purposes suitability as indicated in Table (1).

ArcGIS 10.2.2 [9] is used to map the location of each water sample. Results of each parameter analyzed for $\mathrm{K}^{+}, \mathrm{Na}^{+}, \mathrm{Mg}^{2+}$ and $\mathrm{Ca}^{2+}$ and $\mathrm{HCO}_{3}{ }^{-}$, $\mathrm{Cl}^{-}, \mathrm{NO}_{3}{ }^{-}, \mathrm{SO}_{4}{ }^{2-}$ and $\mathrm{PO}_{4}{ }^{3-}$ have been mapped by a spatial interpolation technique through Inverse Distance Weighted (IDW) to obtain, thematic layers. The thematic layers have been controlled to delineate the distribution of concentration of major ions, nitrate and phosphate of surface and groundwater samples in the study area.

\section{Results and Discussion}

Hydrochemical parameters

The measurement data and the results of most important physical parameters of the collected water samples including temperature, oxidationreduction potential (ORP), dissolved oxygen (DO), $\mathrm{PH}, \mathrm{EC}$, TDS, and results of chemical analysis of major ions $\mathrm{Na}^{+}, \mathrm{K}^{+}, \mathrm{Mg}^{2+}, \mathrm{Ca}^{2+}, \mathrm{HCO}_{3}^{-}, \mathrm{Cl}^{-}, \mathrm{SO}_{4}{ }^{2-}$ and nutrients $\left(\mathrm{NO}_{3}^{-}, \& \quad \mathrm{PO}_{4}^{3-}\right)$ are recorded in Table (2).

The surface water temperature ranged from 16.3 to $21.5^{\circ} \mathrm{C}$ with an average of $18.4^{\circ} \mathrm{C}$, while the groundwater samples temperature ranged between 19.0 and $25.3^{\circ} \mathrm{C}$ with an average value of $22.5^{\circ} \mathrm{C}$. For Oxidation-Reduction potential (ORP), the values for surface water samples ranged between 257 to 485 mv. However, for groundwater samples ranged between 227 to $624 \mathrm{mv}$, the high ORP values observed in shallow wells are reflective of oxic conditions and low values reflect reducing conditions.

The $\mathrm{PH}$ values of surface water samples ranged from 6.20 to 7.07 with an average value of 6.67. For groundwater samples, the $\mathrm{PH}$ values ranged from 6.20 to 6.67 with an average value of 6.45 and thus, the data were reflective of acidity to slightly neutral conditions may be due to contamination of this water.

TDS values of Ismailia canal water samples were ranged from 328 to $613 \mathrm{mg} / \mathrm{l}$. TDS values of ElTimsah lake were varied from 16730 to 34560 $\mathrm{mg} / \mathrm{l}$ in the middle and western edges of the Lake decreasing than the previous studies that indicated TDS value inside the lake was $40 \mathrm{~g} / \mathrm{l}[10,11]$ which insured the discharge of Ismailia canal and drainage water into the Lake. For groundwater samples, TDS values were ranged from 346 to $1099 \mathrm{mg} / \mathrm{l}$.

Total hardness (TH) of the collected samples was calculated based on classification levels of a previous study[12]. The predominant class for about $70 \%$ of surface water samples was very hard and the rest of samples were hard, while, groundwater samples exhibit very hard class in $55 \%$ and $45 \%$ hard class based on the concentration of $\mathrm{CaCO}_{3}(150-300 \mathrm{mg} / \mathrm{l})$.

The cations are dominated by sodium followed by magnesium and calcium in $60 \%$ of surface water samples. Values of $\mathrm{Na}^{+}$and $\mathrm{K}^{+}$ions are 2.0- 410.0 $\mathrm{meq} / \mathrm{l}$ and $0.2-8.0 \mathrm{meq} / \mathrm{l}$ respectively were compared with those of WHO (2011) [13], about $60 \%$ of samples exceeded the permissible limits for drinking water $(\mathrm{Na}=8.69 \mathrm{meq} / \mathrm{l})$, Whereas $\mathrm{Ca}^{2+}$ and $\mathrm{Mg}^{2+}$ ions varied from $1.3-20$ meq/l and 2.5$160 \mathrm{meq} / \mathrm{l}$ respectively.

The anions in surface water samples are dominated by chloride followed by sulphate and bicarbonate in about $60 \%$ of the samples. Values of $\mathrm{Cl}^{-}$ concentration vary from $1.3-500.0 \mathrm{meq} / \mathrm{l}$ with $60 \%$ of samples exceeding the values of WHO (2011) [13] limits for $\left(\mathrm{Cl}^{-}=7.04 \mathrm{meq} / \mathrm{l}\right)$. Bicarbonate and sulphate concentrations varied from 3- 6 meq/l and 1-91 meq/l respectively.

For about $54 \%$ of the groundwater samples, the cations are dominated by magnesium followed by sodium and calcium. Values of $\mathrm{Na}^{+}$and $\mathrm{K}^{+}$ions are 1-9 meq/l and 0.1-1 meq/l respectively. All these samples are in the permissible limits for drinking water according to WHO (2011) [13] except sample11 $(\mathrm{Na}=9.0 \mathrm{meq} / \mathrm{l}) . \mathrm{Ca}^{2+}$ and $\mathrm{Mg}^{2+}$ ions ranged from $0.4-4 \mathrm{meq} / \mathrm{l}$ and $2-10 \mathrm{meq} / \mathrm{l}$ respectively.

In the groundwater samples, the anions are dominated by bicarbonate followed by chloride and sulphate (about 54\%). Values of $\mathrm{Cl}^{-}$ concentration vary from 1.5 to $4 \mathrm{meq} / \mathrm{l}$ in these samples which is in the limits determined by the WHO (2011) [13] (limits for $\mathrm{Cl}^{-}=7.04 \mathrm{meq} / \mathrm{l}$ ). Bicarbonate vary from 3- $6 \mathrm{meq} / \mathrm{l}$ with an average value of $4.5 \mathrm{meq} / \mathrm{l}$. Sulphate concentration varies from $0.5-9 \mathrm{meq} / \mathrm{l}$.

Distribution maps Figs. (3 and 4) for surface and groundwater illustrate cations and anions using ArcGIS. For the groundwater samples, increment in concentrations occur at some localities might be dissolution or cation -exchange processes. 
H.B. HASSAN. et.al

Table (1): Categorization of the CCMEWQI Method

\begin{tabular}{ccc}
\hline Categorization & Index Value & Water Quality \\
\hline Excellent & $95-100$ & Virtual absence of threat \\
Good & $80-94$ & Minor degree of threat \\
Fair & $65-79$ & Occasionally threatened \\
Marginal & $45-64$ & Frequently threatened \\
Poor & $0-44$ & Almost always threatened \\
\hline
\end{tabular}

Table (2): Results of physical and chemical analysis of collected water sample

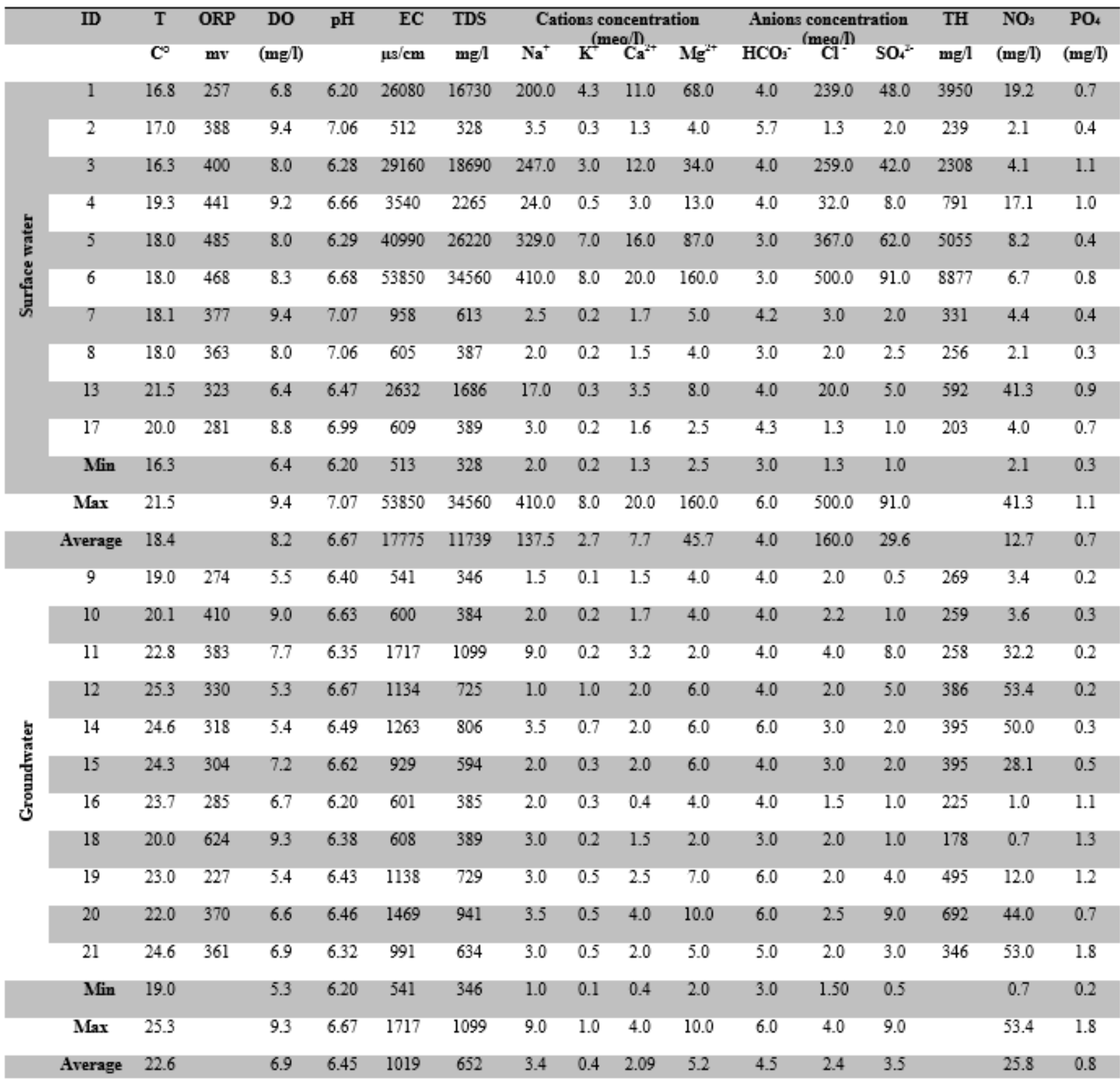




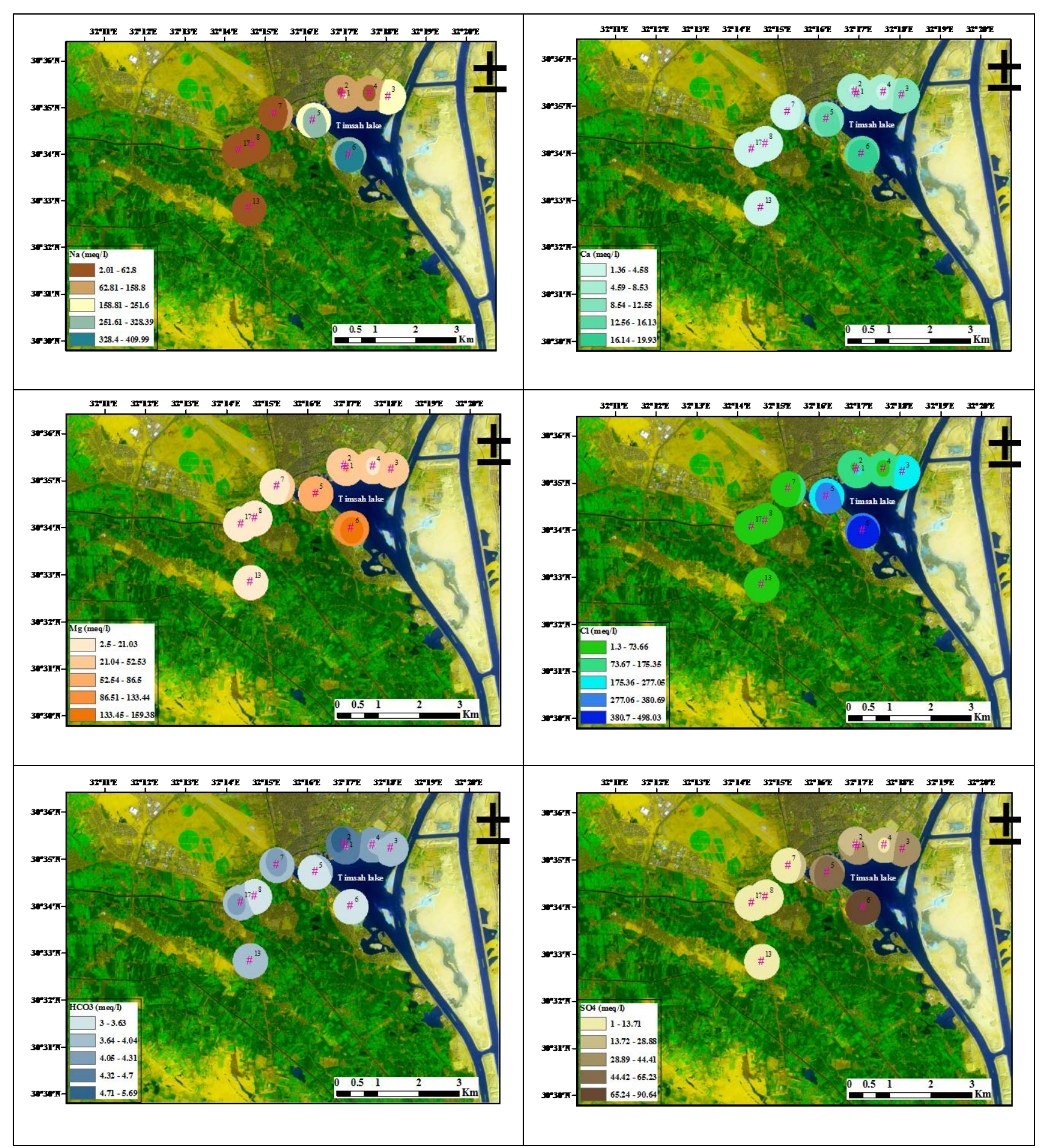

Fig. (3): Distribution of major cations (K, Na, Ca and Mg) and anions (Cl, HCO3 and SO4) of the collected surface water samples 


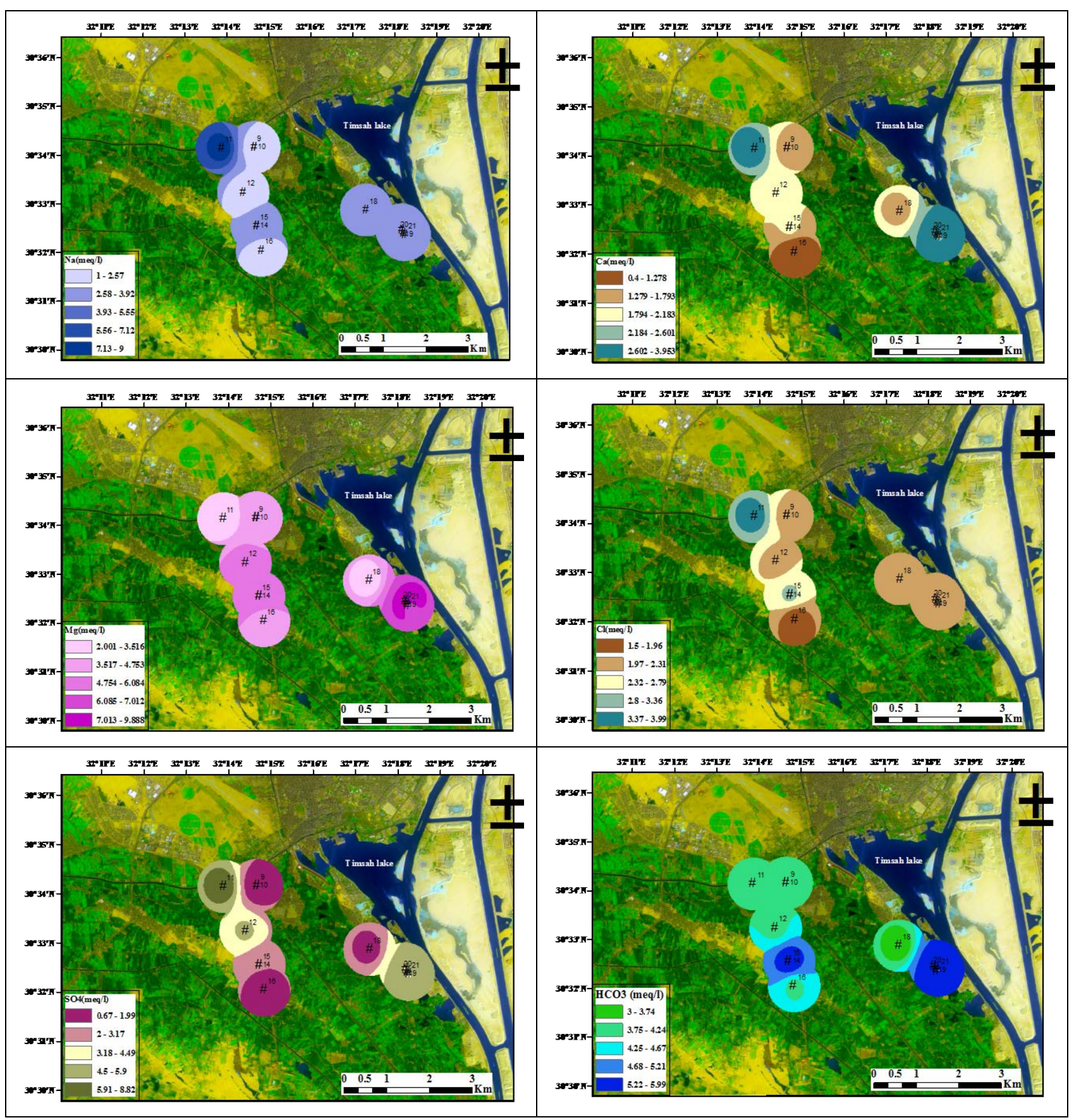

Fig. (4): Distribution of major cations (K, $\mathrm{Na}, \mathrm{Ca}$ and $\mathrm{Mg})$ and anions $\left(\mathrm{Cl}, \mathrm{HCO}_{3}\right.$ and $\left.\mathrm{SO}_{4}\right)$ of the collected groundwater samples 
Piper diagram, [14] is used to clarify chemical changes of the water quality in the study area. The distribution of the surface and groundwater samples in the diamond shape of piper diagram is shown in Fig. (5)

The majority of surface and groundwater samples are located in left subarea of the diamond. These water samples are characterized by dominance of $\mathrm{Ca}, \mathrm{Mg}$ and $\mathrm{Na}$ bicarbonate water type representing fresh water character. The surface water samples have chloride sodium water type. They are directed from the left to the right side of the diamond shape indicating the changes in surface water from lower to higher mineralization state as a result of mixing with drainage and sewage water. Some of the groundwater samples (Nos. 9, 11, 12 and 20) located in top subarea undergo an evolution process along the flow water line by additions of $\mathrm{SO}_{4}^{-2}$ ions. So $\mathrm{Mg}-\mathrm{Na}$ sulphate water type appeared in some groundwater samples.

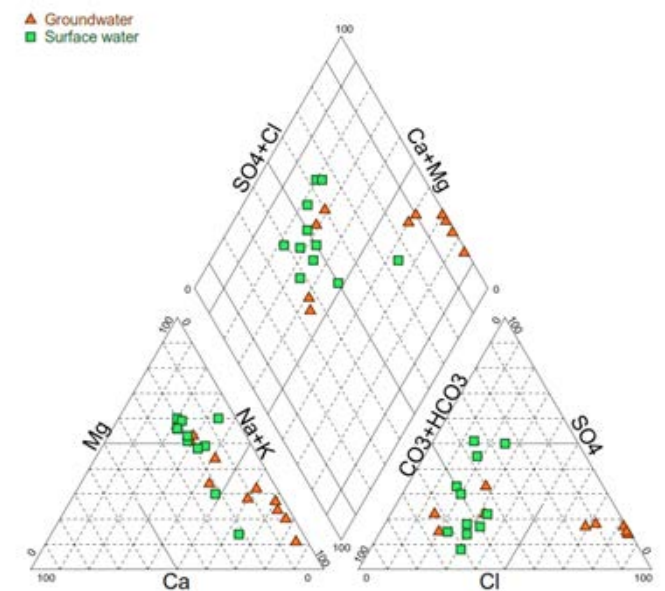

Fig. (5): Piper diagram of the collected water samples

\section{Minor and trace elements contaminants}

Nitrate $\left(\mathrm{NO}_{3}{ }^{-}\right)$

Since most nitrogen compounds are rare in geological formations, these mainly occur in groundwater. Clean natural water typically contains $<10 \mathrm{mg} / \mathrm{l}$ nitrate. In the study area, the sources of nitrate included diffuse and point sources. The nitrate distribution maps (Figures 6a and 6b) for surface and groundwater samples show that nitrate concentrations in surface water varied from $2.1-41.3 \mathrm{mg} / \mathrm{l}$ with an average value of $12.7 \mathrm{mg} / \mathrm{l}$, but for the groundwater samples, nitrate concentrations ranged from $0.7-53.4 \mathrm{mg} / \mathrm{l}$ with an average value of $25.8 \mathrm{mg} / \mathrm{l}$. Nitrate concentration of sample No. 21 was higher than the maximum recommended limit (EPA $>45 \mathrm{mgl}^{-1}$ in drinking water) [15], the highest nitrate values appear in southern and western south parts of the study area in agricultural lands.

\section{Phosphate $\left(\mathrm{PO}_{4}^{3-}\right)$}

The distribution maps of phosphate concentration for surface and groundwater samples are shown in (Figs 7a and 7b) respectively. In the surface water of the study area, it ranged from $0.3-1.1 \mathrm{mg} / \mathrm{l}$ and groundwater samples varied from $0.2-1.8 \mathrm{mg} / \mathrm{l}$ exceeding in some water samples the permissible limits $(0.5 \mathrm{mg} / \mathrm{l})$ [16] that may be affected by sewage water or use of fertilizers in agricultural lands.

\section{Trace Elements Distribution}

Trace elements in subsurface environments may come from natural and anthropogenic sources. Anthropogenic sources include fertilizers, industrial effluents and leakage from service pipes may contribute to trace elements sources. The results of trace elements concentrations including $\mathrm{Al}, \mathrm{B}, \mathrm{Ba}, \mathrm{Bi}, \mathrm{Cd}, \mathrm{Co}, \mathrm{Cr}, \mathrm{Cu}, \mathrm{Fe}, \mathrm{Mn}, \mathrm{Mo}, \mathrm{Ni}, \mathrm{Pb}$, $\mathrm{Si}, \mathrm{Sr}, \mathrm{V}$, and $\mathrm{Zn}$ are shown in Table (3).

According to the Egyptian High Committee of Water Guidelines for Drinking Water Purposes (2007) [8] and international drinking water guidelines WHO (2011) [13] some elements exceeded these standard limits for drinking purposes such as (Al, B, Fe, pb, Mo, Mn, Si and $\mathrm{Sr}$ ) and this is due to several factors that control the limits of these trace elements. 


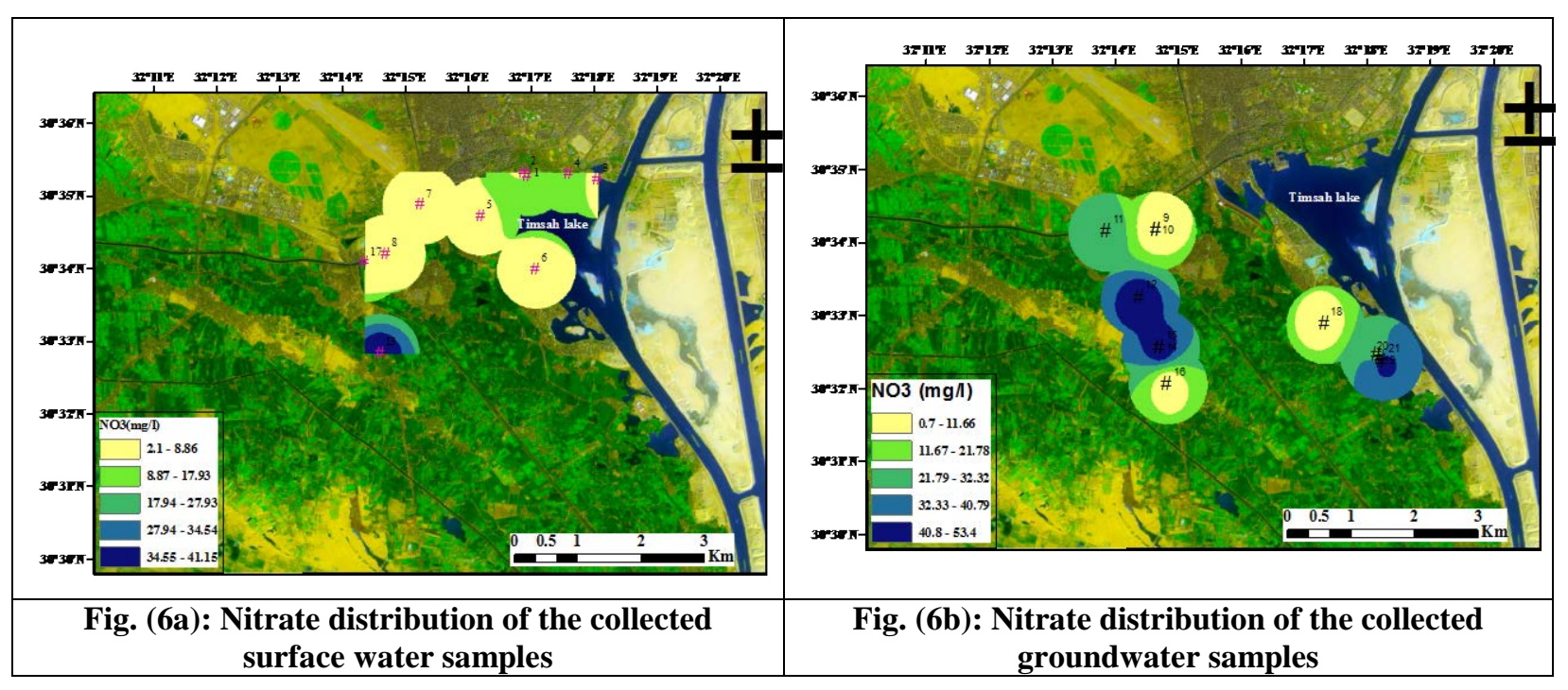

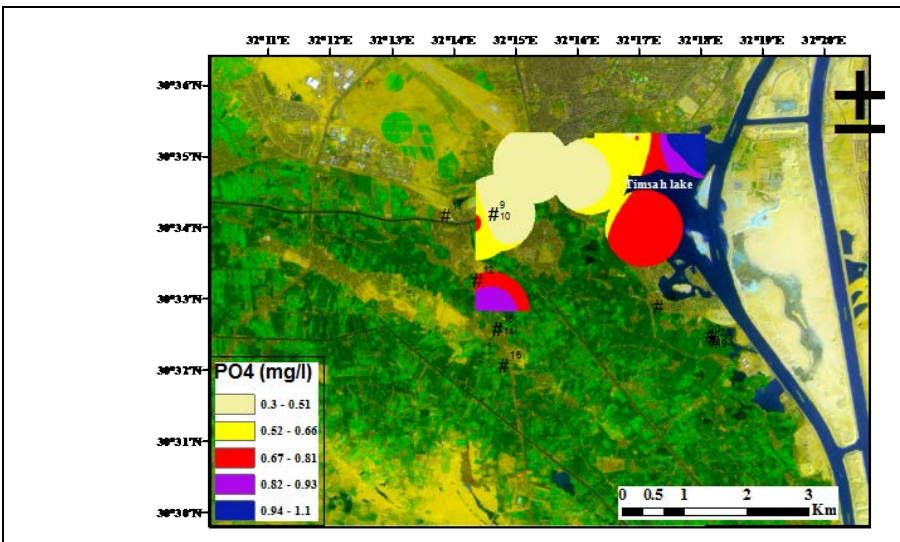

Fig. (7a): Phosphate distribution of the collected surface water samples

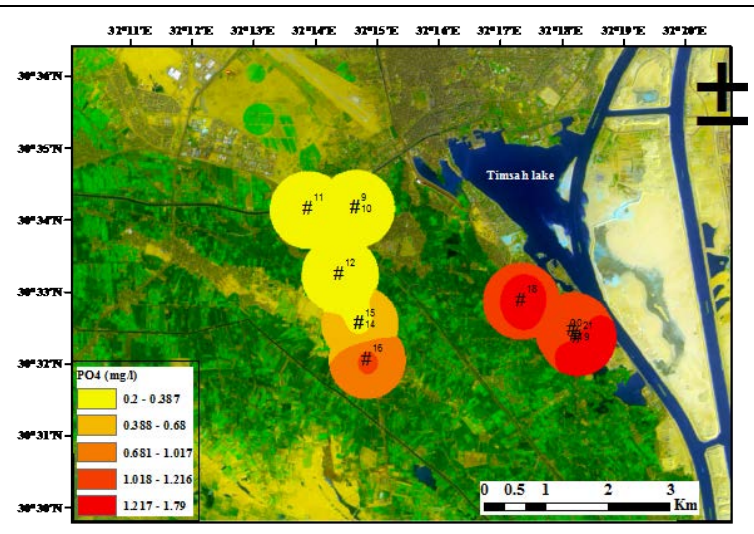

Fig. (7b): Phosphate distribution of the collected groundwater samples

\section{Drinking Water Quality Index (DWQI)}

The overall value of the index (DWQI) helps to classify the water samples into different categories for drinking purposes with consideration of the selected objection based on the Egyptian High Committee of Water [8] as indicated in Table (4). The calculated values of (DWQI) for the study water samples are listed in Table (5). About 30\%, $40 \%$ and $30 \%$ of surface water samples are categorized as poor (Almost always threatened), fair (Occasionally threatened) and marginal (Frequently threatened) respectively. For the groundwater samples, about $36 \%$ of samples are fair

and the rest are good (with Minor degree of threat) for drinking purposes.

\section{Suitability for irrigation uses}

The water used for irrigation especially drainage water has high salinity and excessive values ofsome trace elements which are harmful for soil and plants. The suitability of the surface and groundwater in the study area for irrigation depends on the following parameters: 


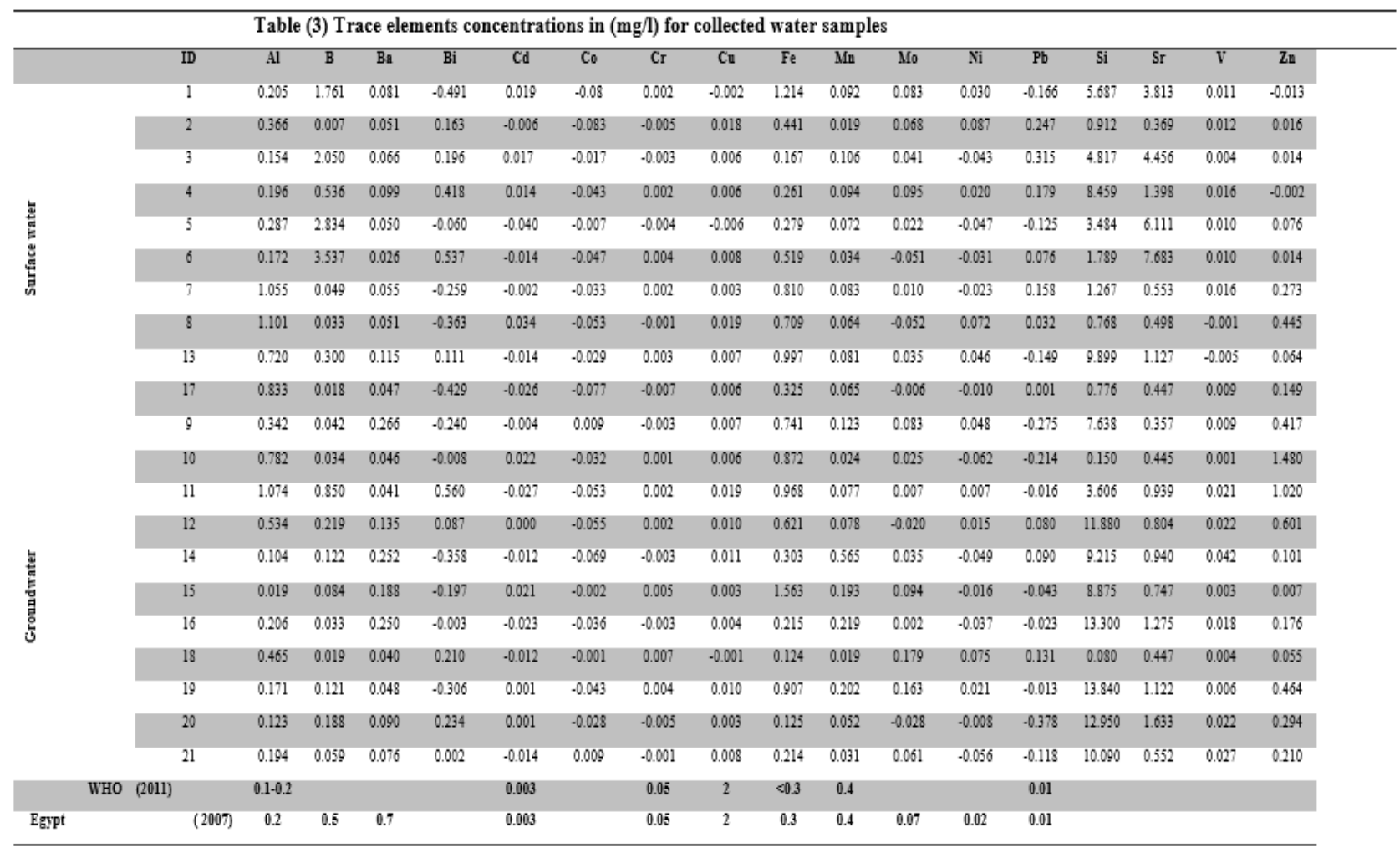

Table (4): Selected Objective based on the Egyptian High Committee of Water

\begin{tabular}{cccc}
\hline Objective & Value & Objective & Value \\
\hline $\mathbf{p H}$ & $6.5-8.5$ & $\mathbf{B}(\mathbf{m g} / \mathbf{l})$ & 0.5 \\
$\mathbf{T D S}(\mathbf{m g} / \mathbf{l})$ & 1000 & $\mathbf{A l}(\mathbf{m g} / \mathbf{l})$ & 0.2 \\
$\mathbf{H a r d n e s s}(\mathbf{m g} / \mathbf{l})$ & 500 & $\mathbf{C r}(\mathbf{m g} / \mathbf{l})$ & 0.05 \\
$\mathbf{C a}^{2+}(\mathbf{m g} / \mathbf{l})$ & 350 & $\mathbf{C d}(\mathbf{m g} / \mathbf{l})$ & 0.003 \\
$\mathbf{M g}^{2+}(\mathbf{m g} / \mathbf{l})$ & 150 & $\mathbf{C u}(\mathbf{m g} / \mathbf{l})$ & 2.0 \\
$\mathbf{N a}^{+}(\mathbf{m g} / \mathbf{l})$ & 200 & $\mathbf{M n}(\mathbf{m g} / \mathbf{l})$ & 0.4 \\
$\mathbf{S O}_{4}{ }^{2-}(\mathbf{m g} / \mathbf{l})$ & 250 & $\mathbf{N i}(\mathbf{m g} / \mathbf{l})$ & 0.02 \\
$\mathbf{C l}^{-}(\mathbf{m g} / \mathbf{l})$ & 250 & $\mathbf{P b}(\mathbf{m g} / \mathbf{l})$ & 0.01 \\
$\mathbf{M o}(\mathbf{m g} / \mathbf{l})$ & 0.07 & $\mathbf{Z n}(\mathbf{m g} / \mathbf{l})$ & 3.0 \\
$\mathbf{F e}(\mathbf{m g} / \mathbf{l})$ & 0.3 & & \\
\hline
\end{tabular}


H.B. HASSAN. et.al

Table (5): Results of water quality index (DWQI) calculations for collected water samples

\begin{tabular}{|c|c|c|c|c|c|}
\hline & ID & F1 & F2 & F3 & WQI \\
\hline \multirow{10}{*}{ 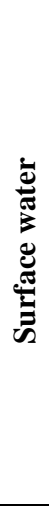 } & 1 & 63.16 & 37.37 & 33.36 & 38.745 \\
\hline & 2 & 21.05 & 37.37 & 12.98 & 65.949 \\
\hline & 3 & 47.37 & 37.37 & 40.03 & 44.983 \\
\hline & 4 & 47.37 & 37.37 & 11.64 & 53.310 \\
\hline & 5 & 47.37 & 37.37 & 43.13 & 43.690 \\
\hline & 6 & 47.37 & 37.37 & 52.30 & 39.331 \\
\hline & 7 & 15.79 & 37.37 & 9.87 & 68.277 \\
\hline & 8 & 26.32 & 37.37 & 9.91 & 64.465 \\
\hline & 13 & 47.37 & 37.37 & 4.92 & 54.004 \\
\hline & 17 & 10.53 & 37.37 & 1.68 & 70.473 \\
\hline \multirow{11}{*}{ 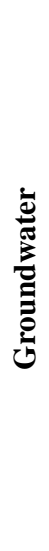 } & 9 & 26.32 & 18.18 & 1.71 & 75.661 \\
\hline & 10 & 15.79 & 18.18 & 5.06 & 81.302 \\
\hline & 11 & 36.84 & 18.18 & 3.58 & 68.664 \\
\hline & 12 & 15.79 & 18.18 & 4.44 & 81.394 \\
\hline & 14 & 21.05 & 18.18 & 3.81 & 78.665 \\
\hline & 15 & 10.53 & 18.18 & 2.13 & 83.954 \\
\hline & 16 & 10.53 & 18.18 & -0.07 & 87.869 \\
\hline & 18 & 26.32 & 18.18 & 7.76 & 74.990 \\
\hline & 19 & 15.79 & 18.18 & 1.51 & 99.521 \\
\hline & 20 & 15.79 & 18.18 & 0.48 & 81.699 \\
\hline & 21 & 5.26 & 18.18 & -0.08 & 85.617 \\
\hline
\end{tabular}

Sodium Adsorption Ratio (SAR)

Sodium is communally measured for water to be used for agricultural purposes [18] particularly irrigation. The sodium adsorption ratio (SAR) is used to evaluate the suitability of water for irrigation. The ratio estimates the degree which sodium will be adsorbed by the soil. High value of SAR implies that sodium in the irrigation water may replace calcium and magnesium ions in the soil, potentially causing damage to the soil structure. The SAR value is defined as follows:

\section{SAR $($ epm $)=\mathrm{Na} / \sqrt{ } \mathrm{Ca}+\mathrm{Mg} / 2$}

By applying the U.S. Lab salinity hazard diagram as shown in Fig. (8) on the surface and groundwater samples, it is found that $18 \%$ of groundwater samples are plotted in the zone of medium salinity and low sodium content. It is suitable for soil irrigation. $36 \%$ of the groundwater are classified with high salinity and SAR (>C4-S4) that might be unsuitable for irrigation purposes. $60 \%$ and $30 \%$ of the surface water samples are classified by high and medium salinity with low sodium content respectively that can be used for soil irrigation.

\section{Sodium Percentage (\%)}

The higher quantities of sodium than the limited value in soil decrease the infiltration rate, soil permeability and hydraulic conductivity due to swelling and dispersions of clays (Shainberg, 1990)[18]. The sodium percentage $\mathrm{Na} \%$ in the surface and groundwater samples is calculated by the equation:

$$
\mathrm{Na} \%=\frac{\left(\mathrm{Na}^{+}+\mathrm{K}^{+}\right) x 100}{\mathrm{Ca}^{2+}+\mathrm{Mg}^{2+}+\mathrm{Na}^{+}+\mathrm{K}^{+}}
$$

The sodium percentage $(\mathrm{Na} \%)$ of surface water groundwater samples ranges between 28.5 to 84.5 $\%$ and 20 to $63.8 \%$ respectively. Analytical data is represented by Wilcox diagram as shown in Fig (9) relating to sodium percentage $\mathrm{Na} \%$ [19]. It is shown that $36 \%$ of the groundwater samples are unsuitable for irrigation purposes and $27 \%$ of are excellent for irrigation. $60 \%$ of the surface water samples are good for irrigation purposes.

Environmental stable isotope 
The isotope techniques use the environmental stable isotope $\left({ }^{18} \mathrm{O}, \mathrm{D}\right)$ in the groundwater in its relation with surface water to provide information concerning water origin, flow, mixing and sources of pollution occur through the infiltration to the aquifer in the study area.

Table (6) shows the results of analysis of the studied samples. The $\left({ }^{18} \mathrm{O}\right.$ and $\left.\mathrm{D}\right)$ of surface water varies in the range from 1.75 to $3.44 \%$ and 13.8 to $28.21 \%$ respectively. Values of $\left({ }^{18} \mathrm{O}\right.$ and $\left.\mathrm{D}\right)$ of groundwater differ from 2.54 to $3.39 \%$ and 22.95 to $27.97 \%$ respectively.

The data vary in narrow ranges reflecting symmetry of the surface and groundwater. The surface water is slightly enriched and has lower dexcess values compared to groundwater reflecting evaporation process. The isotopic values for surface, groundwater are expressed in the following equation:

$$
\delta \mathrm{D}=6.21 \delta^{18} \mathrm{O}+7.19
$$

The distribution of the surface and groundwater samples $\delta^{18} \mathrm{O}$ and $\delta \mathrm{D}$ as shown in Fig. (10) confirms the interaction between surface and groundwater at gradient where samples mostly in the upper right zone close to the recent Nile water (3.36\% and 24.4\%o) [20] However, water irrigation canals and drains have slightly enriched values due to evaporation process that occurs in the surface water bodies during the recycling of water that used for irrigation.

El- Temsah lake water samples (3, 5, and 6) have slightly elevated than the isotopic value $\delta^{18} \mathrm{O}$ and $\delta \mathrm{D}$ of the Red Seawater (1.98 \%o and $13.8 \%$ ) [21], which may be attributed to high discharge of Ismailia water canal into the lake [22].

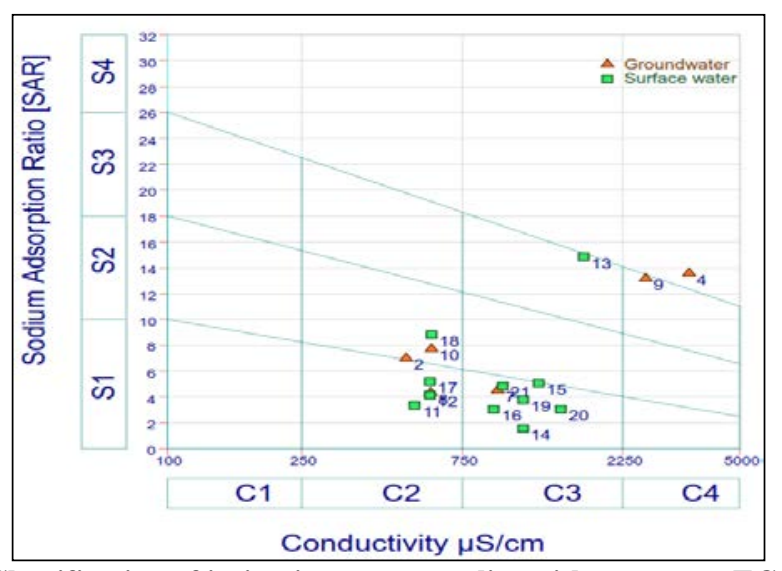

Fig. (8): Classification of irrigation water quality with respect to EC and SAR

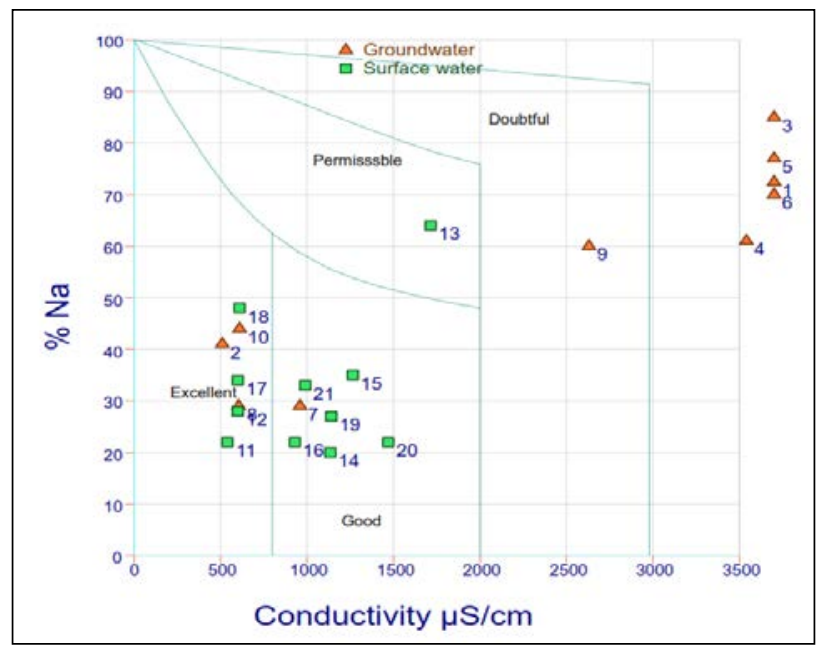

Fig. (9): Classification of irrigation water quality with respect to EC and Sodium Percent 
Table (6): Results of stable isotopes for collected water samples

\begin{tabular}{|c|c|c|c|c|}
\hline \multirow{11}{*}{ 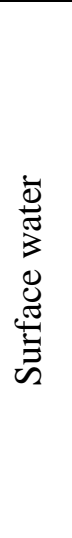 } & ID & $\delta 0^{18}$ & бD \%o & d- excess \\
\hline & 1 & 3.0 & 26.20 & -2.20 \\
\hline & 2 & 3.44 & 28.21 & -0.69 \\
\hline & 3 & 2.0 & $14.32 *$ & 1.68 \\
\hline & 4 & 3.20 & 26.0 & -0.40 \\
\hline & 5 & 1.95 & $14.30 *$ & 1.30 \\
\hline & 6 & 1.75 & $13.80^{*}$ & 0.20 \\
\hline & 7 & 3.01 & 26.13 & -2.05 \\
\hline & 8 & 3.05 & 26.26 & -1.86 \\
\hline & 13 & 2.43 & 20.93 & -1.49 \\
\hline & 17 & 3.06 & 26.41 & -1.93 \\
\hline \multirow{10}{*}{ 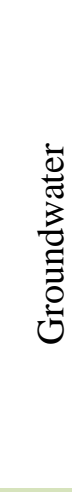 } & 9 & 3.19 & 27.37 & -1.85 \\
\hline & 10 & 2.94 & 25.84 & -2.32 \\
\hline & 12 & 2.65 & 23.78 & -2.58 \\
\hline & 14 & 2.79 & 24.12 & -1.80 \\
\hline & 15 & 3.39 & 27.97 & -0.85 \\
\hline & 16 & 3.27 & 27.82 & -1.66 \\
\hline & 18 & 3.06 & 26.50 & -2.02 \\
\hline & 19 & 2.54 & 22.95 & -2.63 \\
\hline & 20 & 3.12 & 26.03 & -1.07 \\
\hline & 21 & 3.19 & 26.90 & -1.38 \\
\hline \multirow{2}{*}{\multicolumn{2}{|c|}{ Red Seawater ${ }^{(21)}$}} & 3.36 & 24.40 & 2.48 \\
\hline & & 1.98 & 13.80 & 2.04 \\
\hline
\end{tabular}

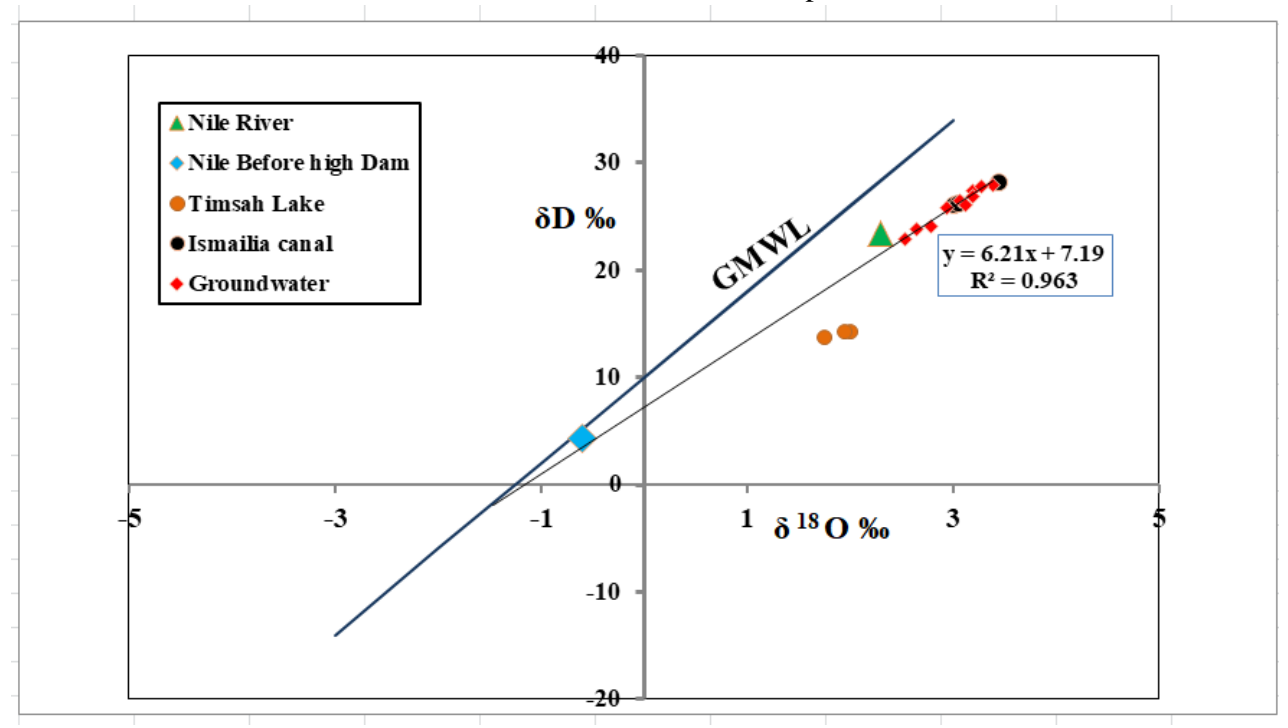

Fig (10): $\delta^{18} \mathrm{O}$ vs $\delta \mathrm{D}$ in \%o relationship of the collected surface and groundwater samples

\section{Conclusion}

The potential effects of anthropogenic activities, in particular, unsafe sewage disposal practices, on shallow groundwater in an unconfined aquifer and 
on surface water were evaluated in the area between El-Timsah lake and Ismailia Canal by the use of hydrochemical, and environmental stable isotopes analyses. These data were obtained from the surface (Ismailia Canal, El- Forsan and ElMahsama drains and El-Timsah Lake) and groundwater samples. Hydrochemical data reveal that TDS values of Ismailia Canal water samples ranged from 328 to $613 \mathrm{mg} / \mathrm{l}$. TDS values of ElTimsah lake varied from 16730 to $34560 \mathrm{mg} / \mathrm{l}$ in the middle and western edges of the lake decreasing than the previous studies that indicated TDS value inside the lake was $40 \mathrm{~g} / \mathrm{l}$ which insured the discharge of Ismailia Canal and drainage water into the lake. For the groundwater samples, TDS values ranged from 346 to $1099 \mathrm{mg} / \mathrm{l}$.

In the surface water of the study area, phosphate concentration ranged from 0.3-1.1 mg/l was less than that of the groundwater samples that varied from $0.2-1.8 \mathrm{mg} / \mathrm{l}$ which may be affected by sewage water or the use of fertilizers in agricultural lands. Nitrate and phosphate concentrations in the groundwater reached 53.4 and $1.8 \mathrm{mg} / \mathrm{l}$ respectively which are slightly above the permissible limits. According to the Egyptian High Committee of Water Guidelines for Drinking Water Purposes (2007) and international drinking water guidelines WHO (2011), concentrations of trace elements (Al, B, Fe, Mn, Pb, Si and Sr) exceeded these standard limits. The results of CCME-WQI Method indicated that about 30\%, $40 \%$ and $30 \%$ of the surface water samples are categorized as poor (Almost always threatened), fair (Occasionally threatened) and marginal (Frequently threatened) respectively. For groundwater samples, about $36 \%$ of samples are fair and the rest are good (with Minor degree of threat). Thus, most of the groundwater is suitable for drinking purposes, but some wells in were threatened due to increasing salinity.

In the study area $\delta^{18} \mathrm{O}$ and $\delta \mathrm{D}$ isotopic content of Ismailia canal ranged from $3.01 \%$ to $3.44 \%$ and 26.0 to $28.2 \%$ respectively. Values of $\left({ }^{18} \mathrm{O}\right.$ and $\left.\mathrm{D}\right)$ of the groundwater differ from 2.54 to $3.39 \%$ and 22.95 to $26.97 \%$ respectively. The convergence of these isotopic content $\delta^{18} \mathrm{O}$ and $\delta \mathrm{D}$ reflect interaction between Ismailia water canal, drainage water and groundwater.

In conclusion, the results demonstrate the deterioration of surface and groundwater sources due to the fact that the water table is shallow and non-renewability of Timsah Lake enhances this effect. El- Timah lake act as a natural discharging water body that receives discharge of Ismailia canal and drainage water.

\section{References}

1. I. Z. El Shamy and M. H. Geriesh (1991): Hydrogeology of West Ismailia area, Egypt. Desert Inst. Bull., Egypt, vol. 42, pp. 271-288.

2. EEAA (Egyptian Environmental Affairs Agency) (2010): Annual Report for the Survey Program of the Egyptian Lakes Lake ElTemsah, pp: 1-10.

3. M. I. GAD, M. M. El-Kammar and H. M. G. Ismail (2015): Groundwater vulnerability assessment using different overlay and index methods for Quaternary aquifer of Wadi ElTumilat, East Delta, Egypt Asian Review of Environmental and Earth Sciences, 2(1): 9-22.

4. M. Gaber (1993): Geology of the northern reaches of the Suez Canal area and ts surroundings. Annals of Geological Survey of Egypt, v, xix (1993) p 513-523.

5. M. H. Geriesh (1989): Hydrogeological investigations of West Ismailia Area, Egypt. M.Sc. Thesis, Fac. of Sci., Suez Canal Univ., Egypt.

6. Z. El Shamy (1992): "Hydrogeology of Wadi El Tumilat and surroundings, East of the Nile Delta, Egypt," 8th Symp. Phaner. Develop., Egypt.

7. Canadian Council of Ministers of the Environment (CCME) (2001): Canadian water quality guidelines for the protection of aquatic life: CCME Water Quality Index 1.0, Technical Report. In: Canadian environment quality guidelines, 1999, Canadian Council of Ministers of the environment, Winnipeg.

8. Egyptian Higher Committee for Water (EHCW) (2007): Egyptian Standard for Drinking Water and Domestic Uses (in Arabic).

9. L. Bing, J. Yao, Q. Liqing, (2011): Research on the model of Nam Co lake water level evolution based on GIS. Procedia Environmental Sciences 10, 1513 - 1518

10. Hamed A. El-Serehy, Hala S abdallah, Khaled A. S Al-Rashed (2018): Assessing water quality and classifying trophic status for scientifically based managing the water resources of the Lake Timsah, The lake with salinity stratification along the Suez Canal. Saudi journal of biological sciences

11. Alaa I. Khedr , Yosry A. Soliman, Esaam F El-Sherbeny , Mohamed A. Hamed, Mohamed A Ahmed, Mohamed E. Goher (2019): Water Quality Assessment of the northern part of 
Suez Gulf (Red Sea, Egypt), using Principal Component Analysis. Egyptian Journal of Aquatic Biology \& Fisheries Zoology Department, Faculty of Science, Ain Shams University, Cairo, Egypt. ISSN 1110 - 6131 Vol. 23(4): 527 - 538 (2019)

12. C.N. Sawyer and Mc P.L. Carty (1967): Chemistry for sanitary engineers. $2^{\text {nd }}$ edition, Mc Graw Hill, New York, 518p.

13. World Health Organization (WHO) (2011): Guidelines for drinking water quality, World Health Organization Geneva, $4^{\text {th }}$ Ed., Recommendations, 1-4.

14. A.M. Piper (1944): A graphic procedure in the geochemical interpretation of water analysis. American Geophysical Union Transactions, Vol. 25, pp. 914- 923.

15. 1U. S. EPA (1985a): Ambient water quality criteria for Copper. 1984. U.S. Environmental Protection, Agency, Office of Water Regulations and Standards, Washinton, DC.

16. D. Chapman (1996): Water quailty assessments. UNESCO/ WHO/ UNEF, 601p.

17. L.A. Richards (1969): Diagnosis and Improvement of Saline and Alkaline Soils, US salinity labrotary staff. Agriculture handbook No. 60.

18. Schainberg, I. (1990): Soil response to saline and sodic conditions in Agriculture Salinity Assessment and Management. Manuals Prac. No. 71, pp. 91-121.

19. Wilcox, L. V. (1955): Classification and use of irrigation waters. Washington, United State department of Agric. (Circ. No.969).

20. Salem W. M., (1996): Application of isotopic and hydrochemical techniques to study groundwater in the eastern Nile Delta and assessment of pollution in Lake Manzala. (PhD thesis) Cairo Uni. Fac. of Engineering.

21. H. Craige (1966a): Isotopic composition and origin of the Red Sea and Salton Sea brines. Science, 154; 1544- 1547.

22. H. B. Hassan,; M. M. Emara,; I. A. ElSabbagh,; M. S. Hamza and S. G. Abd ElSamie (2007): Assessment of Pollution in the Marine Environment in Suez Canal Ph. D., Thesis. Faculty of Science Al- Azhar University (Girls). 